\title{
Presidential Electoral Influence in Congressional Districts, Public Approval, and Presidential Success in Congress
}

\author{
Youseop Shin
}

\begin{abstract}
This paper proposes the electoral influence that the president can exert over legislators as a condition under which presidential popularity generates different influence over legislators. With the two types of presidential support scores in the $95^{\text {th }}$ to $110^{\text {th }}$ House of Representatives as the dependent variable, this paper provides supporting evidence for the argument. Nationallevel presidential popularity has been posited as an important resource that presidents can use for their success in Congress. National-level presidential popularity, however, does not consistently show a significant effect on legislators' voting decisions and it remains as a puzzle why this is so. To solve this puzzle, this paper proposes the electoral influence that the president can exert over legislators as a condition under which national-level presidential popularity generates different influence over legislators. Presidential electoral influence was measured by comparing a president's electoral strength and legislators' electoral strength in congressional districts. With the two types of presidential support scores (non-unanimous support scores and key vote support scores) in the 95th to 110th House of Representatives during the five most recent (Jimmy Carter, Ronald Reagan, George H. Bush, William Clinton, and George W. Bush) administrations as the dependent variable, this paper provides supporting evidence for the argument. National-level presidential popularity exerts a small amount of influence over legislators' voting decisions, as suggested by previous studies. However, according to the findings of this paper, the effect of national-level presidential popularity on legislators' support for the president can increase, as the president can exert a greater influence over legislators in congressional elections.
\end{abstract}

Key Words: presidential support score, presidential popularity, presidential influence, presidential success in congress, president, legislators

Q everal factors related to the president have been posited as resources that the $\checkmark$ president can use for his success in Congress. Among them, presidential pop-

\footnotetext{
*Youseop Shin(sys64@yonsei.ac.kr) is Associate Professor of Political Science at Yonsei University, Seoul, South Korea. He has written on interest group politics, legislative politics, subjective attitudes, and political behavior in the Journals, such as Korea Observer, Korean Journal of International Studies, Korean Political Science Association, Operant Subjectivity, Pacific Focus, and Public Choice.
}

The Korean J ournal of International Studies Vol.13-2 (August 2015), 431-440. http://dx.doi.org/10.14731/kjis.2015.08.13.2.431

(c) 2015 The Korean Association of International Studies 
ularity is one that has been most frequently employed. Presidential popularity, however, does not consistently show a significant effect on legislators' voting decisions and it remains as a puzzle why this is so.

To solve this puzzle, this article considers the possibility that the effect of presidential popularity on individual legislators' support of the president varies according to presidential electoral influence over legislators. Previous studies have assumed that, as a president becomes more popular nationwide, his influence over legislators' vote decisions also increases.

In this paper, we propose the district-level presidential electoral influence over legislators, which can be measured by comparing a president's electoral strength and legislators' electoral strength in congressional districts, as a condition that changes the effect of national-level presidential popularity on legislators' support for the president. We examine the relationship between presidential popularity and legislators' presidential support scores in the $95^{\text {th }}$ to $110^{\text {th }}$ House of Representatives and present evidence for the argument. In the next section of this paper, the theoretical perspective and hypothesis are developed, followed by a description of the model in the third section, the estimation and results in the fourth section, and the conclusion in the fifth section.

\section{PUBLIC APPROVAL AND PRESIDENTIAL LEGISLATIVE INFLUENCE}

Studies have tried to provide evidence for the relationship between national-level presidential popularity and presidential success in Congress. Most of them have provided mixed evidence (Bond and Fleisher 1984 and 1990; Bond et al. 2003; Brace and Hinkley 1992; Cohen et al. 2000; Collier and Sullivan 1995; Edwards 1997 and 1998; Fleisher and Bond 2000; Rivers and Rose 1985; Zeidenstein 1985). It remains as a puzzle why presidential popularity does not consistently show a significant effect on legislators' voting decisions.

Some studies employed state-level presidential popularity measures to analyze presidential success in the Senate, arguing that the presidential popularity hypothesis had not been appropriately tested by previous studies. However, evidence is also mixed at the state level (Cohen et al. 2000; Durham et al. 2003).

It is not appropriate to replace national-level presidential popularity with district-level presidential popularity in the model of presidential legislative success. The president represents the entire country. Therefore, whether or not nationallevel presidential popularity significantly influences legislators' vote decisions is worthy of scholarly concern. A national-level measure needs to be included in the 
model in order not to completely disregard the possibility that the president, with his national-level popularity, can influence his success in Congress. What we need to do is to refine the model so that the effect of national-level popularity on legislators' support for the president can be more appropriately analyzed. To this end, some studies have explored conditions that determine the extent to which a president can capitalize on his public approval (Canes-Wrone and Marchi 2002).

With regard to the relationship between presidential legislative success and national-level presidential popularity, we propose the district-level presidential electoral influence over legislators as a condition that changes the effect of nationallevel presidential popularity on presidential success in Congress. As King (1983) describes, although the president needs legislators, on the face of it, legislators may have no great need of the president. Thereby, the overall effect of presidential popularity on congressional voting is expected to be marginal, as observed in previous studies. In congressional districts where a president got higher levels of support in the last election, however, the probability that his popularity may influence the upcoming congressional election is greater. When a president got higher levels of support in their districts, legislators are more likely to pay attention to presidential popularity because the political cost of resisting the president, especially the cost related to their electoral prospects (Gronke et al. 2003), may become greater than the potential gain.

The probability that presidential popularity may influence the upcoming congressional election is greater in districts where a president got higher levels of support in the last election. Therefore, the effect of presidential popularity on presidential success in Congress are expected to be positively related to the degree to which a president can exert influence over legislators in their districts.

\section{DATA AND METHOD}

To test the hypothesis, a multiple ordinary least squares regression analysis is employed and the relationship between national-level presidential popularity and legislators' presidential support scores in the $95^{\text {th }}$ to $110^{\text {th }}$ House of Representatives during the five most recent (Carter, Reagan, H. Bush, Clinton, and W. Bush) administrations is examined. We do not include the Obama administration because it is not over yet, and therefore we cannot include the entire administration in the analysis. The analysis may be expanded to include additional past or future administrations. However, we do not expect the finding to be significantly different from ours that is based on the 32 years of observations. Alternatively, we may focus on an administration, such as the Nixon and Ford 
administrations, providing a more specific discussion. In this case, however, the generalizability of our explanation may reduce.

We employ non-unanimous support scores and key vote support scores as the dependent variable. The non-unanimous support score is a restrictive index of presidential support in votes on which the winning side numbered less than 80 percent of those who voted. The key vote support score is a more restrictive index of presidential support in votes that are annually identified by Congressional Quarterly according to the following criteria: a matter of major controversy, a test of presidential or political power, and a decision of potentially great impact on the nation and on lives of Americans. These two measures have advantages over the overall support score. The overall support score includes votes on the non-controversial issues, which are nearly unanimously decided, weighing all issues equally. However, legislators are not likely to encounter conflict on these issues in their field of vision (Clausen 1973; Kingdon 1992). Consequently, the overall support score may overestimate legislators' support of the president (Edwards 1989; Bond et al. 1991).

The key vote score may be most precise: it includes only those votes that are important to both legislators and the president. Using key votes, we can assume with confidence that legislators actually considered the president's positions. However, as the measure becomes more restrictive, the number of available votes and consequently the generalizability of findings may reduce. For this reason, we employ non-unanimous support score and key vote support score, respectively, as the dependent variable to test the hypothesis. The two dependent variables come from the Presidential Data Archive, Texas A\&M University.

The independent variables include Presidential Popularity, Presidential Influence, Popularity · Influence, Presidential Party, Ideology, Unified Government, and President indicators (Reagan, H. Bush, Clinton, and W. Bush). Presidential Popularity is the percentage of those who approved of the way the president was handling his job. Based on the Gallup Poll, yearly indices of popularity were calculated. Presidential Influence measures whether and how much a president led or trailed individual legislators in their districts (Harmon and Brauen 1979). It subtracts legislators' vote percentages from presidential districtlevel vote percentages. When a president led a legislator, this variable will have a positive value, and when a president trailed a legislator, it will have a negative value. Popularity - Influence is the interaction term between Presidential Popularity and Presidential Influence. This interaction term is included to consider the possibility that the effect of national-level presidential popularity might be different among legislators according to the degree to which a president led or trailed legislators in the previous election. The higher the value, the more influ- 
ence the president is expected to have over legislators with his popularity. The effect of national-level presidential popularity that has been discussed by previous studies is not likely to be fully represented because this interaction term was not included in the model.

Presidential Party, Ideology, Unified Government, and four president indicators are included as control variables. Presidential Party equals one to presidential party members who are expected to be predisposed to support the president and zero to opposition party members. Ideology is measured with a DWNominate score (Poole and Rosenthal 1998) for Republican presidents. For Democratic presidents, a DW-Nominate score is multiplied by -1. As legislators are ideologically more conservative, their presidential support scores are expected to be higher for Republican presidents and lower for Democratic presidents. Unified Government equals one if the House of Representatives has a majority of members in the same party as the president. It takes into consideration the possibility that the president might be less successful under a divided government than under a unified government. Divided control is expected to weaken presidential leadership in Congress and translate the healthy competition between the political parties to win the election into an unhealthy conflict between the institutions of government themselves (Sundquist 1988). Also, partisan differences are expected to magnify the institutional separation of powers between the pres-

Table 1. Descriptive Statistics

\begin{tabular}{l|l|l|l|l}
\hline & Mean & Std. Dev. & Min. & Max. \\
\hline Non-unanimous Support Score & 48.75 & 28.63 & 0 & 100 \\
\hline Key Vote Support Score & 47.17 & 31.34 & 0 & 100 \\
\hline Popularity & 52.44 & 10.68 & 30.03 & 72.18 \\
\hline Popularity · Influence & -956.11 & 1051.77 & -6481.76 & 1848.00 \\
\hline Presidential Influence & -18.18 & 19.23 & -92.00 & 33 \\
\hline Presidential party & .49 & .50 & 0 & 1 \\
\hline Ideology & .01 & .41 & -.97 & 1.26 \\
\hline Unified government & .38 & .48 & 0 & 1 \\
\hline Reagan & .25 & .43 & 0 & 1 \\
\hline H. Bush & .13 & .33 & 0 & 1 \\
\hline Clinton & .25 & .43 & 0 & 1 \\
\hline W. Bush & .22 & .41 & 0 & 1 \\
\hline $\mathrm{n}$ & 13723 & & & \\
\hline
\end{tabular}

Note: The listwise deletion method was used. 
ident and Congress, which in turn will increase institutional conflicts so that policies are decided through an institutionally structured bargaining process, where each party has a veto (Cox and Kernell 1991). Reagan, H. Bush, Clinton, and W. Bush equal one for each of these presidents and zero for the others. They are included to control for variations in the mean presidential support scores among the included presidents. Their coefficients will denote differences in the mean presidential support scores between these presidents and Carter, the excluded category in the dummy variable scheme. Table 1 gives descriptive statistics for the dependent and independent variables included in the analysis.

\section{FINDINGS}

Table 2 reports the results of the multiple regression analysis. Perusing the table, it is apparent that the hypothesis is maintained, no matter which type of scores is analyzed. The interaction term, Popularity · Influence, consistently exerts significant influence over legislators' support scores. As hypothesized, presidential electoral influence in congressional districts significantly changes the amount of influence that the president can exert over legislators with his national-level popularity.

Table 2. Presidential Popularity and Presidential Scores, 1977-2008

\begin{tabular}{|c|c|c|}
\hline & Non-unanimous Score & Key Vote Score \\
\hline Popularity & $.054(.015, .02)^{\star \star *}$ & $.322(.023, .11)^{\star \star *}$ \\
\hline Popularity $\cdot$ Influence & $.001(.001, .044)^{\star \star}$ & $.01(.001, .33)^{\star \star \star}$ \\
\hline Presidential Influence & $-.054(.028,-.04)^{*}$ & $-.531(.042,-.33)^{\star \star \star}$ \\
\hline Presidential party & $6.36(.49, .11)^{\star \star *}$ & $4.641(.734, .074)^{\star * *}$ \\
\hline Ideology & $55.76(.63, .79)^{\star \star \star}$ & $54.49(.96, .71)^{\star \star *}$ \\
\hline Unified Government & $6.09(.36, .103)^{* \star *}$ & $-1.948(.544,-.03)^{\star * *}$ \\
\hline Reagan & $11.74(.48, .18)^{\star \star \star}$ & $-3.89(.73,-.054)^{\star \star \star}$ \\
\hline H. Bush & $10.35(.56, .12)^{\star \star \star}$ & $6.34(.84, .07)^{\star \star \star}$ \\
\hline Clinton & $11.23(.44, .17)^{\star * *}$ & $7.766(.67, .107)^{\star \star \star}$ \\
\hline W. Bush & $3.57(.38, .05)^{* * *}$ & $5.102(.581, .067)^{\star * *}$ \\
\hline Constant & $32.57(.81)^{\star * *}$ & $22.31(1.22)^{\star * *}$ \\
\hline $\mathrm{n}$ & 13724 & 13723 \\
\hline $\mathrm{p}$ & $<.000$ & $<.000$ \\
\hline Adj. $R^{2}$ & .796 & .609 \\
\hline
\end{tabular}

Note: The first numbers in parentheses are standard errors and the second numbers in parentheses are standardized coefficients. 
As the presidential electoral influence increases in a congressional district, he appears to be more able, with his national-level popularity, to improve the probability that he will be supported by the legislator from the district. For example, according to the coefficients of Presidential Popularity and Popularity Influence in the first column, each 10 percentage rise in national-level presidential popularity would produce a 0.64 point increase in non-unanimous support scores when the president led a legislator by 10 percent in the previous election, and a 0.44 point increase when the president trailed a legislator by 10 percent in the previous election. According to the coefficients of Presidential Popularity and Popularity - Influence in the second column, each 10 percentage rise in nationallevel presidential popularity would produce a 4.2 point increase in key support

Figure 1. Interaction between Presidential Popularity and Presidential Influence

Non-unanimous Vote

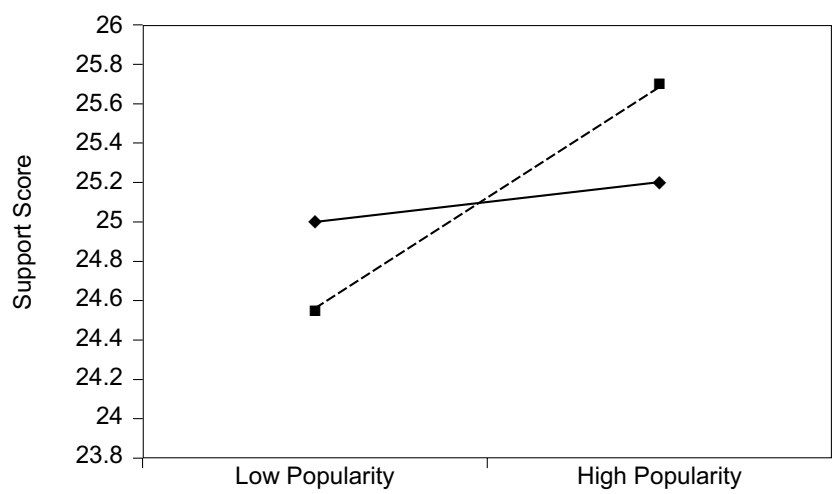

Key Vote

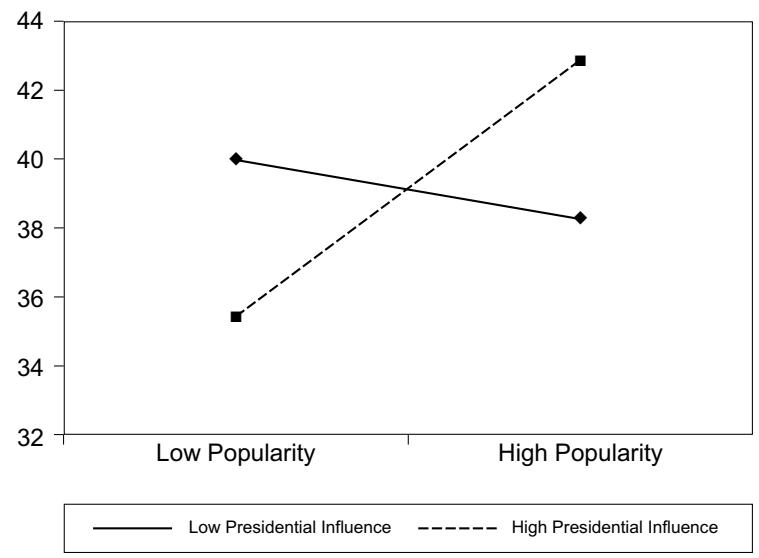


scores when the president led a legislator by 10 percent in the previous election, and a 2.2 point increase when the president trailed a legislator by 10 percent in the previous election. Figure 1 graphically presents the interaction effects in Table 2. As expected, Popularity and Popularity - Influence exert a greater influence over legislators in key votes than in non-unanimous votes. This may indicate that legislators tend to pay greater attention to the president's popularity and his electoral influence when they deal with more controversial and important issues.

As shown in previous studies, national-level presidential popularity exerts a small influence over legislators' support for the president. According to Table 2, however, its influence can increase according to the president's district-level electoral performance in the previous election. The change in the non-unanimous support score for each 10 percentage rise in presidential popularity when Presidential Influence moves from its observed minimum value to its observed maximum value (see Table 1) was 1.79. The change in the key vote support score for each 10 percentage rise in presidential popularity when Presidential Influence moves from its observed minimum value to its observed maximum value was $15 \cdot 72$.

According to the standardized coefficients, presidential popularity's additional effect through the interaction with presidential electoral influence is greater than the direct effect of Presidential Influence (the first column) or similar to that (the second column).

\section{CONCLUSION}

In this paper, we showed that the effect of national-level presidential popularity on legislators' support for the president can increase, as the president can exert a greater influence over legislators in congressional elections. The findings of this paper do not reverse the conventional argument that presidential popularity has a limited effect on presidential legislative success. Even together with its interaction term, presidential popularity explains a small amount of variance of presidential support scores.

Previous studies that tested the presidential popularity hypothesis with a national-level presidential popularity measure alone, however, inaccurately assumed that the president should be able to exert the same amount of influence across legislators with his national-level popularity. The effect of presidential popularity on presidential legislative success will not be fully represented if it is not considered together with district-level presidential electoral influence.

According to the finding of this paper, we need to explore conditions under 
which presidential popularity exert the intended influence over legislators. In the process, we will improve our understanding of the relationship between presidential popularity and legislators' voting decisions and, more generally, the relationship between the president and the Congress.

\section{REFERENCES}

Bond, John R. and Richard Fleisher. 1984. "Presidential Popularity and Congressional Voting: A Reexamination of Public Opinion as a Source of Influence in Congress." Western Political Quarterly 37, 291-306. . 1990. The President in the Legislative Arena. Chicago: University of Chicago press.

Bond, John R., Gary W. Copeland, Lance T. LeLoup, Russell D. Renka, and Steven A. Shull. 1991. "Implications for Research in Studying Presidential-Congressional Relations: Conclusion.” In Steven A. Shull ed., The Two Presidencies. Chicago: Nelson-Hall Publishers.

Bond, John R., Richard Fleisher and B. Dan Wood. 2003. "The Marginal and Time-Varying Effect of Public Approval on Presidential Success in Congress." Journal of Politics 65(1), 92-110.

Brace, Paul and Barbara Hinkley. 1992. Follow the Leader: Opinion Polls and the Modern Presidents. New York: Basic Books.

Canes-Wrone, Brandice and Scott de Marchi. 2002. "Presidential Approval and Legislative Success.” Journal of Politics 64(2), 491-509.

Cohen, Jeffrey E., John R. Bond, Richard Fleisher, and John A. Hamman. 2000. "State-Level Presidential Approval and Senatorial Support." Legislative Studies Quarterly 25(4), 577-590.

Collier, Kenneth and Terry Sullivan. 1995. "New Evidence Undercutting the Linkage of Approval with Presidential Support and Influence." Journal of Politics 57(1), 197-209.

Cox, Gary W. and Samuel Kernell, eds. 1991. The Politics of Divided Government. Boulder: Westview Press.

Durham, Brandy M., Jeffrey E. Cohen, Richard Fleisher, and Jon R. Bond. 2003. "The Effects of State Level Presidential Approval on Support in the Senate." Paper presented at the annual meeting of the Midwest Political Science Association, Chicago.

Edwards, George C. III. 1976. "Presidential Influence in the House: Presidential Prestige as a Source of Presidential Power.” American Political Science Review 70(1), 101-113. 
1989. At the Margins: Presidential Leadership of Congress. New Haven: Yale University Press.

. 1997. "Aligning tests with Theory: Presidential Approval as a source of Influence in Congress." Congress and the Presidency 24, 113-130.

Fleisher, Richard and Jon R. Bond. 2000. "Partisanship and the President's Quest for Votes on the Floor of Congress." In Richard Fleisher and Jon R. Bond eds., Polarized Politics: Congress and the President in a Partisan Era. Washington D.C.: CQ Press.

Gronke, Paul, Jeffrey Koch, and J. Matthew Wilson. 2003. "Follow the Leader? Presidential Approval, Presidential Support, and Representatives's Electoral Fortunes.” Journal of Politics 65(3), 785-808.

Harmon, Kathryn N. and Marsha L. Brauen. 1979. "Joint Electoral Outcomes as Cues for Congressional Support of U. S. Presidents.” Legislative Studies Quarterly 4(2), 281-299.

King, Anthony. 1983. Both Ends of the Avenue. Washington: American Enterprise Institute.

Poole, Keith T. and Howard Rosenthal. 1998. "The Dynamics of Interest Group Evaluations of Congress." Public Choice 97(3), 323-361.

Rivers, Douglas and Nancy Rose. 1985. "Passing the President's Program: Public Opinion and Presidential Influence in Congress." American Journal of Political Science 29(2), 183-196.

Sundquist, James. 1988. "Needed: A Political Theory for the New Era of Coalition Government in the United States." Political Science Quarterly 103(4), 613-635.

Zeidenstein, Harvey G. 1985. "Presidents' Popularity and their Wins and Losses on Major Issues in Congress: Does One Have Greater Influence over the Other?” Presidential Studies Quarterly 15(2), 287-300. 